University at Buffalo School of Law

Digital Commons @ University at Buffalo School of Law

\title{
Aesthetic Judgment and Legal Justification
}

\author{
Guyora Binder \\ University at Buffalo School of Law
}

Follow this and additional works at: https://digitalcommons.law.buffalo.edu/journal_articles

Part of the Common Law Commons, and the Jurisprudence Commons

\section{Recommended Citation}

Guyora Binder, Aesthetic Judgment and Legal Justification, 43 Stud. L. Pol. \& Soc'y 79 (2007).

Available at: https://digitalcommons.law.buffalo.edu/journal_articles/276

This article is (c) Emerald Publishing Limited and permission has been granted for this version to appear here (http://digitalcommons.law.buffalo.edu). Emerald does not grant permission for this article to be further copied/ distributed or hosted elsewhere w

\section{IN COPYRIGHT}

This Article is brought to you for free and open access by the Faculty Scholarship at Digital Commons @ University at Buffalo School of Law. It has been accepted for inclusion in Journal Articles by an authorized administrator of Digital Commons @ University at Buffalo School of Law. For more information, please contact lawscholar@buffalo.edu. 


\title{
AESTHETIC JUDGMENT AND LEGAL JUSTIFICATION
}

\author{
Guyora Binder
}

\begin{abstract}
Although criticized as illegitimate, literary elements are necessary features of legal argument. In a modern liberal state, law motivates compliance by justifying controversial prescriptions as products of an appropriate process for representing the will of society. Yet because law constructs the will of individual and collective actors in representing them, its representations are necessarily figurative rather than mimetic. In evaluating law's representation of society, citizens of the liberal state are also shaping their own ends. Such self-expressive choices, subjective but non-instrumental, entail aesthetic judgment. Thus the literary elements of rhetorical figuration and aesthetic appeal are fundamental, rather than merely ornamental, to legal justification.
\end{abstract}

In the modern liberal state, law is seen as legitimate in so far as it successfully represents popular and individual will. Liberal legal thought tends to equate law's legitimacy with the objectivity and mimetic accuracy of this representation. Thus, law achieves legitimacy by fulfiling democratic will, satisfying preferences, or protecting rights.

Critics of liberal legal thought often respond that law is illegitimate because (1) it does not achieve its claimed objectivity or because (2) its formality precludes it from fully and authentically representing the subjectivity of society's members. In making these arguments, critics of liberal legal thought deploy the analogy of law to literature in antithetical ways. Thus, critiques of the first kind insist that law is too literary - that is, too figurative and imaginative to represent objectively. Critiques of the second kind, however, charge that law is not literary enough that is, insufficiently sensitive and expressive to represent authentically. Both of these arguments treat the literary as an anomaly within law, although for different reasons. The first critique accepts the modern liberal state's aspiration to represent society objectively, and berates it for falling short of this ideal. The second critique presumes the modern liberal state's success in achieving objectivity, but rejects this standard of mimesis in favor of authenticity. Both accept the liberal premise that law should accurately reflect society in its deliberations and

This article is $($ Emerald Publishing Limited and permission has been granted for this version to appear here (https://digitalcommons.law.buffalo.edu). Emerald does not grant permission for this article to be further copied/distributed or hosted elsewhere without the express permission from Emerald Publishing Limited. 
decisions, without changing society. Each criticizes part of modern liberal legal thought's program of objective representation, at the price of endorsing the remainder.

Drawing on pragmatic epistemology, post-structuralist literary theory, and institutionalist critiques of rational choice theory, this chapter rejects liberal legal thought's aspiration to mimetic accuracy. Moreover, it rejects both forms of criticism as expressions of the same flawed aspiration. It treats the charge that law is insufficiently objective as a form of skepticism, and treats the complaint that law effaces authentic subjectivity as a form of sentimentalism. Both critiques are unpragmatic, demanding of law what it cannot possibly - and should not aspire to - deliver. Rather than evaluating law as a mimetic representation of society, this chapter reinterprets law's allocation of decisionmaking authority as a necessarily figurative and constructive representation of society's will. It understands legal argument to make a rhetorical appeal to aesthetic judgment rather than an empirical claim to mimetic accuracy. And it treats the larger question of the legal system's legitimacy as a similarly aesthetic question of expressive validity. Thus, rather than treating the literary as anomalous within law, this chapter treats the literary as inherent in the construction and operation of legal authority.

Like much imaginative literature, law represents subjectivities and their desires. But, also like these types of literature, law's relationship to what it represents is figurative and performative rather than straightforwardly mimetic. Law constructs subjectivities in the process of representing them. In this way it composes and portrays the characters on which it relies for its authority. On this view, legal systems should be judged as much on the basis of the desires and characters they cultivate as on the basis of their efficiency in gratifying those desires or their accuracy in representing those characters. Law's portrayal of society is "true", only in so far as we choose to make it so by identifying ourselves with it. Thus legitimacy involves a performative element, depending on the commitment of those who choose to identify with the law. Law can never simply reflect our authentic selves. Instead, it enables us to express ourselves in certain ways, and thereby precludes us from expressing ourselves in other ways. The question of who we should become is neither simply a question of ethical duty nor an arbitrary matter of consumer choice. Democratic self-fashioning poses value questions, but these value questions call for aesthetic judgment.

One of my aims in laying out this aesthetic account of legal authority is to clarify the conceptual architecture of my book written with Bob Weisberg, Literary Criticisms of Law (Binder \& Weisberg, 2000). The book reviewed and critiqued the emergent law and literature scholarship of the late twentieth century. It incorporated our earlier article "Cultural Criticism of Law" (Binder \& Weisberg, 1997), and drew on other work of ours, including Bob's well-known article "The Law-Literature Enterprise", (Weisberg, 1988). Threaded through Literary Criticisms of Law was an argument that, (1) in the modern liberal state, 
law represents society rhetorically rather than mimetically and (2) the authority of law and the validity of particular legal arguments depend upon aesthetic judgment. In reviewing law and literature scholarship in that volume, we had two aims. One was to collect and explicate works that revealed law's rhetorical and aesthetic dimensions. The other was to expose and critique the skeptical or sentimental premises of much law and literature scholarship. This chapter explicates the critical perspective developed in Literary Criticisms of Law, but does not attempt to illustrate or apply that perspective. It does not address the state of law and literature scholarship because what I have to say on that subject, I have said.

My account of the role of the literary in legal authority will proceed as follows. First, I will develop and explain a conception of literature as rhetorical (i.e. figurative) discourse presented for aesthetic judgment. Second, I will offer a conception of law as a relatively coercive, formal, and justificatory institution. In so doing, I will contrast two models of justification within such an institution: a modernist model that seeks foundations in physiological or psychological facts, and a pragmatist model that tests claims by their implications for practice and evaluates these implications aesthetically. Third, I will offer an account of legal argument as a rhetoric offering narratively structured figurative representations of subjectivity for aesthetic judgment and expressive identification. Finally, I will characterize the skeptical and sentimental critiques of law as expressions of legal modernism and urge that legal justification be accepted as a pragmatic discourse which necessarily employs the literary elements of rhetorical representation and aesthetic judgment.

\section{LITERARY DISCOURSE AND AESTHETIC JUDGMENT}

Let us define literature as any kind of discourse that presents figurative representations or "rhetoric" for aesthetic judgment. Using such a conception, we can identify and analyze literary elements in many kinds of cultural practices, including law.

By figurative or rhetorical language, I mean language that is not purely propositional. Rhetoric refers obliquely, substituting one proposition or other verbal sign for another, rather than substituting a proposition for a state of affairs or a set of sense data. An important claim of post-structuralist literary theory is that all language is figurative. This claim rests on ideas drawn from structuralist linguistics and pragmatist philosophy of language. Structuralism treats language as an organization of the experienced world rather than a set of labels for prelinguistic objects or sensations. On the structuralist view signs are given their

This article is (c) Emerald Publishing Limited and permission has been granted for this version to appear here (https://digitalcommons.law.buffalo.edu). Emerald does not grant permission for this article to be further copied/distributed or hosted elsewhere without the express permission from Emerald Publishing Limited. 
meanings not by the sense-experience they organize, but instead by their relations to and differences from other signs within a system (de Saussure, 1959; Culler, 1975). In this sense, every proposition is a trope, evoking all the other propositions it differs from.

Pragmatist philosophy of language shares the premise that thought apprehends the world through language (Peirce, 1931-1935). It holds that scientific data, for example, must be identified and recorded in a language laden with theoretical assumptions (Quine, 1963; Rorty, 1979). In contrast to structuralism, however, pragmatism envisions language as an evolving practice rather than a stable structure. On this view, the meaning of any utterance is its use - the actions and utterances to which it responds, and which predictably follow it. Because verbal meaning is merely customary, subject to evolving patterns of use, the concepts that organize thought can have no stable essence. Utterances are moves in a "language game"' with no predetermined outcome (Wittgenstein, 1968). Such a game presupposes that interlocutors are bound together by activities and institutions; but as the practical context for speech changes and as players respond to utterances in surprising ways, the use and meaning of particular sentences change. Thus every utterance differs not only from other words that might be said on this occasion, but also from the same words that might have been said on previous occasions, but with a different meaning (Hurley, 1989). This temporal differentiation means that every time we speak we are reusing past utterances to stand for new propositions, with open-ended meanings. For post-structuralists this constant reuse of language in an always-different context is a substitution of one sign for another, so that all utterances are rhetorical figures that invite the hearer to interpret an indeterminate meaning (Binder \& Weisberg, 2000; Derrida, 1976; Culler, 1983). The contingency of meaning on the responses of others makes every move in a language game a gamble, requiring what legal theorist Karl Llewllyn called "'situation-sense," a kind of interpretive judgment and gestural grace (Llewellyn, 1960, pp. 60-61).

This view of language as inevitably instable and rhetorical has some fairly straightforward implications for law. Thus, it suggests we are unlikely to control official discretion, or to secure a stable, predictable environment for individual choice, merely by issuing detailed rules (Tushnet, 1988; Levinson, 1988; Lieber, 1839). The qualities of regularity and predictability are not relations of correspondence between prescribed and achieved states of affairs, but instead are feelings that officials have used language and exercised choice in tolerably legitimate ways. Such a feeling is likely to depend on a relatively peaceable context without rapid changes in social status or social norms. In other words stable social practices make it possible to "follow rules," rather than the other way around (Fish, 1989). More importantly, the feeling of regularity is not the product simply of observation or measurement, but of a necessarily subjective and

This article is (c) Emerald Publishing Limited and permission has been granted for this version to appear here (https://digitalcommons.law.buffalo.edu). Emerald does not grant permission for this article to be further copied/distributed or hosted elsewhere without the express permission from Emerald Publishing Limited. 
evaluative judgment on the part of some socially situated observer. This is an ultimately aesthetic judgment about the way that officials perform their roles.

If all speech is rhetorical, any speech can function as literature - can have literary meaning - in so far as it is subjected to aesthetic judgment. By aesthetic judgment I mean a conception developed by Kant in the Critique of Judgment, considered the foundation of the modern field of aesthetics (Kant, 1986). Kant took the appreciation of art as the paradigm for aesthetic judgment, but did not limit the concept to such judgments. According to his conception, aesthetic evaluation requires a subjective, concrete, disinterested, judgment of intrinsic value. For Kant, a judgment was an evaluation subject to discursive contestation and justification. Kant certainly did not agree that there is no disputing taste: in principle, one should be able to offer persuasive reasons for an aesthetic judgment, supported by invoking an interlocutor's experience of the sensuous qualities of the object being judged. Yet, neither could logic or empirical evidence ever prove an aesthetic evaluation, or finally settle an aesthetic dispute. Thus aesthetic judgments are subjective rather than objective: they are not determined by logic or by characteristics of the object judged. Ultimately, each individual must be the judge of his or her own aesthetic experience.

An aesthetic judgment is concrete in the sense that it is a judgment of a particular object, unmediated by any concept, rule, or general criterion. Joseph Heller's Something Happened is a fine novel, not because it exemplifies the praiseworthy quality of suspense, but because of the particular way it wrings suspense out of the prosaic details of middle-class family life, as revealed by a narrative speaker determined to keep his anxieties hidden from himself. Thus, the particular way that suspense is expressed in this novel is aesthetically valuable because of its contribution to the novel's unique formal structure. For Kant, the concreteness of aesthetic evaluation distinguishes it from moral evaluation, which measures every action by the same general standard of fairness.

An aesthetic judgment is disinterested in the sense that it is not - although it may accompany - the experience of pleasure. Thus, a tragedy can impress me as great while overwhelming me with sadness; by contrast, a formulaic potboiler might give me just what I want, without impressing me at all. In Something Happened, the reader's eager curiosity is an integral formal element, but so is the reader's dread and discomfort. Particular pleasures may be necessary means to achieve particular aesthetic effects, but the value of such an effect is not reducible to the pleasure producing it. Finally, according to Kant's conception, an aesthetic judgment is a judgment of intrinsic rather than instrumental value. A work of art is not beautiful or great because it causes pleasure, or any other good consequence. It might teach moral virtues, or give insight into human psychology, but such beneficial consequences are distinct from its aesthetic value.

Aesthetic judgment plays a role in artistic expression and in the appreciation and criticism of artistic works. Just as the creation of art cannot be reduced to a

This article is (C) Emerald Publishing Limited and permission has been granted for this version to appear here (https://digitalcommons.law.buffalo.edu). Emerald does not grant permission for this article to be further copied/distributed or hosted elsewhere without the express permission from Emerald Publishing Limited. 
formula, art criticism does not apply general standards of value given in advance of the act of aesthetic judgment. Instead, it informs experience of the object of aesthetic judgment, in such a way as to create a shared or reproducible experience. To the extent that the shared experience made available by a critical interpretation impresses its audience as intrinsically valuable, it becomes possible to derive criteria of value from that shared experience. Aesthetic criticism identifies values expressed by human creations and judges those values on the basis of the shared experience of those creations. Thus, aesthetic criticism is less concerned with applying evaluative standards than with identifying, developing, and assessing values.

Aesthetic judgment can play a role in other kinds of evaluative decisionmaking as well. It is relevant whenever a decisionmaker has a measure of discretion, yet is not simply gratifying her own desires. Typically, this sort of evaluative decision will arise in collective action, which often requires interpreting norms or representing others' interests. Thus, when acting for an organization with an indefinite purpose or multiple purposes, a decisionmaker has to construct the organization's mission in order to serve it. Particularly if the organization depends on the voluntary cooperation of its agents, the decisionmaker must act in a way that will be accepted by others as a coherent interpretation of the organization's past practices and of the participants' community of interest. One who acts for another as a fiduciary rather than an agent often has discretion to interpret the beneficiary's interests, but cannot simply replace those interests with her own. In these situations of interpretation and representation, choice involves judgment rather than preference, and that judgment is partly aesthetic (Simon, 1978; Luban, 1988).

Ronald Dworkin has noted a similarly constructive element inherent in applying customary norms such as courtesy that require adapting conventions to changing social circumstances. Dworkin views this kind of "constructive interpretation" of an existing social practice as an exercise of aesthetic judgment (Dworkin, 1986). Pierre Bourdieu has identified an analogous combination of discretion and constrained judgment in the related social practice of giftexchange. A well-chosen gift should express something about the giver and the receiver; it should differ from the receiver's past gifts to the giver, and yet symbolically equal or requite them (Bourdieu, 1990). The expression of courtesy is an aesthetic effect, but that does not mean it is merely ornamental. Tact facilitates trust, enabling strangers or rivals to achieve the mutual benefits of otherwise "irrational" cooperation. A British diplomat assigned to the Coalition Provisional Authority in occupied Iraq learned that "a cup of coffee delivered in the right way could win more friends than a new high school, and no amount of money could wipe clean an insult.' The relationships with tribal leaders he built on this sort of courtesy enabled him "to secure the release of a British

This article is ( E) Emerald Publishing Limited and permission has been granted for this version to appear here (https://digitalcommons.law.buffalo.edu). Emerald does not grant permission for this article to be further copied/distributed or hosted elsewhere without the express permission from Emerald Publishing Limited. 
businessman,yhanded back to him as a 'present' from the uncle of the kidnapper"' (Skidelsky, 2006, p. 12).

Aesthetic judgment is also required in making decisions about the cultivation of tastes, whether for one's self or another. When parents choose educational environments for a child they are acting as fiduciaries. Hopefully they are acting in the "best", interests of the child rather than simply gratifying their own preferences by unreflectively reproducing themselves or compensating for their own disappointments. Nor would we expect them merely to gratify the current preferences of the child (to do nothing but watch TV for example), who is not yet competent to formulate her own purposes without assistance. The parents are acting in part to determine the preferences and interests of the child by developing her character (Margulies, 1996, p. 1475). The interests that are "best' for this particular child in the long run, in the judgment of those who love and care for her, are interests she does not yet have and perhaps never would develop if raised by different parents with different capabilities and interests. Exercising such judgment is a profoundly serious responsibility, but it is nevertheless at least in part, an aesthetic choice: subjective, disinterested, informed by judgments of intrinsic worth ("best"), but also highly contingent and concrete (what are this child and these parents capable of under these circumstances?).

Similarly, when a young adult makes important decisions with long-term consequences for herself - going to Antioch, entering the military or holy orders, emigrating, getting married, having a child - she is not gratifying her future preferences because those future preferences depend, in large part, on her choices. These kinds of identity-altering choices are better seen as selfexpressive or selffashioning than as self-gratifying. Such choices about what kind of person one would like to become are aesthetic choices in so far as they reflect judgment of what available or achievable roles, interests, and desires are most worthy, or will best realize one's particular potential. The problem of character development that preoccupies modern fiction, drama, and lyric poetry is the problem that confronts us individually and collectively in a liberal society where we are free to define and develop our own virtues, free to - in Nietzsche's telling phrase - " give style", to our characters (Nietzsche, 1974, pp. 185-186; Nehamas, 1985). Imaginative literature engages our aesthetic judgment in this problem, and trains it; but planning the development of character is a problem we face in "real" life.

Following Kant, many thinkers have explored the role of these kinds of aesthetic judgments in politics and law. The poet Friedrich Schiller argued in his Letters on the Aesthetic Education of Man that aesthetic experience was essential preparation for exercising the moral and civic obligations associated with freedom in the new democratic state. Deliberating about and cooperating to achieve the public good required training in empathetic imagination and disinterested evaluation. What would it feel like to be somebody else? What would society be like to live in after this or that legislative change? For Schiller, aesthetic

This article is (c) Emerald Publishing Limited and permission has been granted for this version to appear here (https://digitalcommons.law.buffalo.edu). Emerald does not grant permission for this article to be further copied/distributed or hosted elsewhere without the express permission from Emerald Publishing Limited. 
appreciation was also a kind of motivation necessary for compliance with moral and civic obligation. The creation of a good society, like the creation of art, could become a gratifying calling (Schiller, 1967). Hannah Arendt, in her lectures on Kant's Critique of Judgment, agreed that political persuasion among equals necessarily involves an aesthetic appeal. Democratic politics, for Arendt, is deliberative and transformative: if participants are unwilling to examine and alter their own preferences and identify with collective projects they are merely engaged in bargaining, not politics. Thus a legitimate law does not represent the electorate by reflecting the preferences of a majority of individuals. Instead it constitutes a figurative representation of a collective will that can only come into existence in the deliberative process and through collective action (Arendt, 1992).

Juergen Habermas's neo-Kantian ethical theory treats a deliberative discourse of instrumental and aesthetic evaluation as an indispensable legitimating condition for any legal or political arrangement. Drawing also on pragmatic epistemology, Habermas associates modern rationality with an open-ended process of testing belief, responsive not only to new evidence, but also to new conditions and purposes. For Habermas, deliberation unrestricted by a given end, concept, or object is the condition for justifying propositions in a self-governing society of equals. Habermas sees propositions of any kind as part of an institutional practice of language rather than as copies of sensory experience. Hence their validity is always provisional, dependent on ongoing social practices of evaluation and reason-giving rather than correspondence with objects or concepts. These provisional judgments of legitimacy are partly instrumental because they permit the invocation of those social purposes and practices on which interlocutors can agree. But in so far as those purposes and practices are themselves subject to challenge, interpretation, and revision, judgments of legitimacy are also aesthetic in part. Habermas's major work on legal theory, Between Facts and Norms, emphasizes the interpretive character of deliberation about law. Legal institutions and rules always have an arbitrary, historically contingent character, or "facticity." We tend to accept historically received laws provisionally because by establishing a modicum of social order and peace they facilitate collective action, including the justificatory deliberation that is the condition of legitimacy. The price of this provisional acceptance is the hermeneutic character of legal deliberation, the necessarily imaginative project of making normative sense of historical contingency (Habermas, 1996).

Habermas's reflections on law's historicity or "facticity" respond to two leading post-war hermeneutic theorists of law, Hans-Georg Gadamer and Dworkin. Both argued that legal interpretation was a creative process implicating aesthetic judgment. Gadamer, in Truth and Method, portrayed interpretation of all kinds as a dialogue between text and interpreter in which the interpreter comes to understand herself as a participant in an enabling language and culture rather than a self-determining instrumental actor (Gadamer, 1975). The legal interpreter

This article is $@$ Emerald Publishing Limited and permission has been granted for this version to appear here (https://digitalcommons.law.buffalo.edu). Emerald does not grant permission for this article to be further copied/distributed or hosted elsewhere without the express permission from Emerald Publishing Limited. 
comes to understand the historically contingent legal text as not arbitrary for her, by developing a self-interpretation as a participant in an institutional tradition that generated the text and that enables judgments of meaning and value. Even the interpreter's capacity to criticize existing legal arrangements draws upon a language, society, and history that also gave rise to those arrangements. To protest is to presume that the legal system is at some level bound by the values the protester invokes, so that the legal discourse always contains the germ of its own creative transformation. But that transformation depends on acts of creative selffashioning by interpreters implicated in that discourse. Dworkin, in Law's Empire, offers a similar account of legal reasoning and argument as engaged participation in a legal system, in which a "constructive interpreter' makes sense of received legal materials by imagining the underlying purposes and principles of justice that make the "best" of them. Dworkin calls the hermeneutic obligation to make the best of law "the aesthetic hypothesis." And he likens the interpretive process to reading a legal system's past as the actions of a fictional person and continuing the story in a way that maintains that character's "integrity" in both the aesthetic and the moral senses of that term (Dworkin, 1986).

These thinkers see aesthetic judgment as part of law and politics because they see law and politics as settings for collective self-fashioning. They see political and legal legitimacy as an aesthetic effect, a value judgment that persuades individuals to identify themselves with a particular, historically contingent set of social arrangements and to embrace purposes that are not their own. In developing a conception of law as an object of literary analysis, then, we want to emphasize the role of figurative representations in legitimating law by persuading law's subjects to identify with it, or at least to identify themselves in the terms law provides.

\section{LEGAL INSTITUTIONS}

In recent decades, social scientists in various fields have developed the concept of institutions to capture the causal role of a variety of factors left out of rational choice models of society. These include cultural meanings and values, but also routines and procedures for gathering and processing information, and for allocating decisionmaking authority. The juxtaposition of such seemingly disparate phenomena in the same category suggests surprising connections among them. Thus, for example, we can think of decisionmaking procedures as semiotic relations, in which person $\mathrm{A}$ is authorized to decide or act on behalf of person $\mathrm{B}$ or organization $\mathrm{C}$; or in which facts $\mathrm{D}$ and $\mathrm{E}$ are taken as conclusive evidence of quality F. Similarly, we can conceive of virtues and value commitments as the performance of roles, such as the good Catholic, the neutral judge, or the obedient soldier. On this view, persons acting out value commitments serve as symbols, 
standing for something beyond their own preferences. Because institutionalism presents both substantive and procedural norms as semiotic relations involving a kind of representation, it offers a perspective that may illuminate law's literary aspect.

Drawing on the institutionalist literature, we may define institutions as social practices organizing collective action through a discourse that classifies situations as subject to rules or other normative standards. Thus defined, institutions have a normative dimension, involving rule-following; a semiotic dimension, concerned with representing situations as instances of a class; and a social dimension, involving organization for collective action. Institutions sometimes also have a political dimension, concerned with the distribution of authority to make and apply normative judgments, and the distribution of responsibility to follow norms. Thus, institutions frequently classify persons as well as situations and apply so condition the application of normative standards on particular roles or statuses (MacCormick \& Weinberger, 1986; March \& Olsen, 1989; North, 1990; Peters, 1999; Ruiter, 1993; Scott, 1995; Searle, 1995). Institutions include almost any socially organized activity, such as science or art. Language, which organizes collective action through conventional representations that are subject to normative standards of referential and grammatical correctness, is an institution on which most other institutions depend. Money, a system of rules for representing exchange value, that facilitates exchange and resource allocation, is also an institution.

Given a conception of an institution as a practice of using norms to organize collective action, we can define law as including any institution that is relatively coercive, formal, and articulate. So legal institutions involve norms of conduct understood, in principle, to be binding on persons recognized as occupying certain statuses, whether or not those individuals accept those obligations. These conduct norms are backed by sanctions, imposed by some persons at the request of others, according to norms of participation, investigative procedure, decision, and discursive justification.

Finally, the process of generating all these norms is governed by additional norms of participation, procedure, and discursive justification (Komesar, 1997; Hart, 1994). The formality of law consists in the prevalence of norms of participation and procedure in the discourse of legal justification. Most legal questions are resolved by identifying the authoritative decisionmaker, the past decisions of such an actor, or the standards authorized by such an actor, rather than by directly invoking values or goals.

To characterize law as an institution is to say that it conditions participation on the acceptance of norms and the performance of roles. Institutional roles channel action by supplying actors with a set of motives, concerns, and assumptions and a limited repertoire of behaviors. Roles render action intelligible and predictable to others (Bourdieu, 1991; Bourdieu, 1977; Binder \& Weisberg, 1997). The 
desires to communicate to others or to be associated with certain roles can therefore motivate compliance with norms. In other words, people can comply with norms out of expressive rather than instrumental motives.

As an institutional practice, then, law commands not only or ultimately by threatening. Law orders society through the combined effects of coercive force and normative authority. Norms without force are not laws, but commands are not laws unless they are obeyed also out of a sense of obligation. Moreover, law's force and its authority are integrally connected. On the one hand, law can muster manpower and weapons only because many people agree that its commands should be obeyed. On the other hand, the availability of coercive force enhances law's authority. Because many will prefer any effective legal system, however unjust, to anarchy or violent civil conflict, force tends to generate its own legitimacy. To view law as an institution, however, is to emphasize the role of law's normative authority in inducing compliance and legitimizing state force. That authority is a cultural construct, real in so far as people believe it to be so.

The authority of many institutions is a matter of unreflective habit. We usually accept money as valuable and language as meaningful without reflecting about how and why this is so. But law is different, at least in modern liberal states. Law is an arena of contestation and legal authority depends upon a self-conscious discourse of justification. In making legal arguments, participants of course try to establish the validity of particular propositions of law. Yet in so doing they also endorse the authority of law generally, warranting the rationality of the forum in which they appear, the validity of the statutes, prior cases and principles they cite, and the legitimacy of the process that generated these sources of law.

A practical incentive to justify arises only when we need to - and can hope to - influence the behavior of others with some power to withhold cooperation. We justify actions and beliefs where contestation is possible but there are nevertheless common norms to appeal to. Thus, a discourse of justification is most likely in institutional settings characterized by a relative equality among participants, and a measure of freedom of action. Indeed, we may say that a distinctive characteristic of modern liberal societies is the proliferation of justificatory practices that presuppose this kind of freedom and equality. Justificatory discourse in such a society usually involves more than invocation of hierarchical status or tradition (Ackerman, 1980). Law, with its self-conscious discourse of justification, becomes a paradigm for other modes of institutional authority in such a society.

Let us define modernity as a discursive situation premised on the epistemological principle that all knowledge must derive from human experience or reason, rather than tradition or faith; and the meta-ethical principle that all value must derive from human will or reason, rather than tradition or faith (Patterson, 1996; Lyotard, 1984). Modernity gives rise to the practice of modernist criticism, which tests beliefs by reducing them to their foundations in sensation, will, and

This article is $($ Emerald Publishing Limited and permission has been granted for this version to appear here (https://digitalcommons.law.buffalo.edu). Emerald does not grant permission for this article to be further copied/distributed or hosted elsewhere without the express permission from Emerald Publishing Limited. 
reason. In the field of law, such reductionist movements as utilitarianism, legal positivism, legal science, legal realism, critical legal studies, and law and economics have exemplified modernist criticism (Bentham, 1996; Austin, 1873; Williston, 1920; Cohen, 1935; Singer, 1984; Posner, 1973).

Modernity shapes justificatory discourses as responses to modernist criticism. In the face of normative disagreement, modernist justificatory discourse has a tendency to discount reason and to root values entirely in some form of will or desire. Justificatory reference to desire may be teleological (interests, utility, welfare, needs), or archaeological (consent, preferences, injuries). Reason (or "rationality") may then be accorded a subordinate role in directing action to serve desire, or in reconciling conflicting desires through deliberation or aggregation. These variants of modernist justificatory discourse share a common assumption: that practices can only be justified by correspondence to observed fact. This insistence on a foundation in fact arises from modernism's mistrust of the discourses of representation on which institutional practices depend. Modernist criticism treats the need for representation as an embarrassment. Thus, it strives to reduce these representations, or signs, to the "reality" they represent - ideas, sense impressions, desires, intentions, verbal meanings, material interests, behavior, and so forth. From this perspective, representations have meaning or value by virtue of their correspondence to some state of affairs. In short modernist criticism presumes that representation has a mimetic function (Patterson, 1996; Ankersmit, 1996).

In epistemology, modernist criticism asks "what is it about the world that our statements must conform to, to make them true?' In philosophy of language, it asks "what must a claim about the meaning of language correspond to, to make it true?" Philosophers' answers to these questions have generally taken the form of an intelligible essence, or some similar mental entity. Thus, rationalists held that knowledge was founded on clear and distinct ideas. Empiricists complained that these ideas were unobservable specters, and replaced them with sense impressions and mental associations. As pragmatists pointed out, however, empiricists thereby reproduced the idealism for which they had criticized the rationalists. Empiricists assumed we could only understand, use, and communicate about our environment if it came equipped with mental handles for words to grasp onto (Rorty, 1979). As argued in the preceding section, however, this idea of a direct linkage between words and features of the world mischaracterizes how we use language. Linguistic and literary structuralists have pointed out that signifieds, what words denote or connote, are linguistic constructs, no less dependent on a system of conventional signs than are their verbal signifiers (Binder \& Weisberg, 2000). Pragmatic philosophers of language and literary post-structuralists have converged on the view that these signifieds are shifting webs of association rather than hard-edged concepts or categories. The meaning of any term is hostage to the evolving history of its use. Because no

This article is (c) Emerald Publishing Limited and permission has been granted for this version to appear here (https://digitalcommons.law.buffalo.edu). Emerald does not grant permission for this article to be further copied/distributed or hosted elsewhere without the express permission from Emerald Publishing Limited. 
two occasions of use are identical, every use of language is rhetorically figurative, and every act of communication or interpretation is a speculative move in a language game (Wittgenstein, 1968; Hurley, 1989; Derrida, 1976; Binder \& Weisberg, 2000). Every classificatory judgment is a normative claim within an institutional practice that may be accepted, rejected, or reinterpreted by others.

Pragmatism takes the failure of philosophy's varied attempts to translate language and thought into unmediated reality, as evidence that the task should be abandoned. Pragmatism therefore rejects the assumption that representation must stand in a relation of correspondence with the world, in order to be meaningful (Rorty, 1979). Instead, pragmatism views representations simply as tools for organizing social practices, and holds that their necessarily unstable meaning inheres in their use. Since the same utterances can be used by both speakers and hearers, by multiple authors and later by different readers, there is never any single spatial and temporal locus of meaning, no ultimate authority on what any utterance means. Representation, in the sense used here - the use of signs within an institutional practice - is never purely mimetic. It is always figurative and always offered for normative judgment.

The disagreement between modernism and pragmatism about representation extends to the special case of political representation. Political representation is a form of collective action involving (1) a division of labor that allocates power to persons acting in designated roles to promulgate or apply norms backed by coercive sanctions and (2) a justificatory discourse ascribing these exercises of power to others. Persons may be represented by particular other persons, or by organizations, within which different persons may have different roles (Ankersmit,1996; Pitkin, 1967). Political representation is a common institutional structure in modern legal systems, and the justificatory discourse of political representation is an important source of legal argument.

Just as modernist epistemology and philosophy of language have looked for a third term to explain how representations can correspond to what they represent, modernist political theory has done the same. Political theory asks what about us political institutions must represent to make their representation legitimate. The answers - preferences, interests, opinions, convictions - purport to be psychological facts about persons. But like any other signified, these objects of representation depend upon the system of signs that differentiates them from other signifieds (Ankersmit, 1996; Hurley, 1989). Thus, we need an agenda, a menu of options, in order to have an opinion. We need issues, establishing political axes, before we can locate our political positions on those axes (Pildes \& Anderson, 1990; Mackie, 2003). In this sense, the political preferences electoral and legislative institutions represent are "endogenous" to those institutions (Hurley, 1989; March \& Olsen, 1995; Green \& Shapiro, 1994). Political representations, therefore, cannot correspond to social fact. They cannot achieve mimetic truth.

This article is (c) Emerald Publishing Limited and permission has been granted for this version to appear here (https://digitalcommons.law.buffalo.edu). Emerald does not grant permission for this article to be further copied/distributed or hosted elsewhere without the express permission from Emerald Publishing Limited. 
They must win normative acceptance from those they represent on some other basis.

Based on its view of representation as inherently rhetorical, pragmatism also offers an account of both cognitive and evaluative justification that rejects the mimetic premise of modernism. Pragmatic justification makes the test of any action or belief the difference it makes in practice. It asks us to compare the consequences of any action or claim with the consequences of available alternative actions or claims. But unlike other consequentialist doctrines, such as utilitarian policy analysis or verificationist epistemology, pragmatism does not prescribe further criteria for comparing alternative bundles of consequences. It treats the justification of action and belief as a matter of situated practical judgment, and denies that justification must rest on a foundation of indubitable knowledge (Rorty, 1979; Patterson, 1996; Herzog, 1985; Binder, 2001).

Aesthetic judgment has a special role to play in the consequentialist evaluation required in pragmatist justification. Pragmatism asks us to evaluate consequences without the metric provided by some foundational standard of value. It is tempting to assume that this means we should simply assess consequences instrumentally, by reference to the purposes we already have. But this evades such questions as what feasible choices we have among purposes, what the consequences would be of choosing different purposes, whether those consequences would be better or worse, and from what perspective. We cannot employ instrumental reason to evaluate ends: this is a question of aesthetic judgment (Binder, 2001). Thus, in so far as legal justification is pragmatist rather than modernist, it will involve a rhetorical appeal to aesthetic judgment.

\section{THE RHETORIC OF LEGAL JUSTIFICATION}

Legal justification is a rhetoric that makes an aesthetic appeal. It combines three types of rhetorical figures. The most important of these is the political representation of subjective will. In a modern liberal state, law is seen as a human creation, designed to serve human needs (Cardozo, 1921). Accordingly, law's content is justified by reference to the utility or choice of human beings or their institutional representations. Legal argument and decision therefore involve prospective reasoning about the interests of persons, groups, populations, institutions, and polities; and retrospective reasoning about the content and competence of their choices. In other words, almost all legal argument is about the desires of legal actors, how best to measure, identify, or represent those desires, and whose desires should count (Binder \& Weisberg, 1997; Binder, 2001).

These political representations of subjective will are framed by three forms of narratives: narratives of reconciliation, narratives of authorization, and narratives

This article is (c) Emerald Publishing Limited and permission has been granted for this version to appear here (https://digitalcommons.law.buffalo.edu). Emerald does not grant permission for this article to be further copied/distributed or hosted elsewhere without the express permission from Emerald Publishing Limited. 
of legitimation. Narratives of reconciliation are the rhetorical structures used to explain how the will of each becomes the will of all. Thus, they explain how the invisible hand of the market reconciles the competing desires of consumers into efficient allocations of resources; or how political processes organize the incommensurable preferences of voters into a coherent popular will; or how wise judges rationally reconcile the competing liberty claims of litigants. In other words, narratives of reconciliation warrant particular decisionmaking procedures as methods for representing society as a whole. Narratives of authorization link a particular act to the will of all, in the form of a past authoritative decision or a future societal goal. Finally, narratives of legitimation warrant the subjective will of society itself as an authoritative source of law by linking it to some greater source of virtue in the past or future.

"Narrative" refers to the recounting of a story, a chronological sequence of causally linked events in the experience of a human or anthropomorphized subject. A narrative is a kind of rhetorical trope, a structure of meaning imposed on events by their selection, ordering, and telling. It begins in equilibrium, presenting a stable routine of behaviors and roles. This equilibrium is then disturbed by some conflict, often between the subject and forces external to it, which disrupts routines and roles, opening new possibilities. The story ends in a new state of equilibrium (Binder \& Weisberg, 2000; Winter, 1989; Scholes \& Kellogg, 1966; Todorov, 1971). The mediation of such a story by a teller rather than performers distinguishes narrative from drama, but both are mediations distinct from events themselves (Scholes \& Kellogg, 1966). In modern culture, the activity of a narrator alerts an audience to the artifactual or subjectively constructed quality of the story, even when the resulting narrative is nonfictional (Binder \& Weisberg, 2000).

Narrative, like drama, makes a sensuous appeal to an audience's judgment by creating the aesthetic quality of suspense. It evokes tension by describing disequilibrium, and suspends that tension by recounting events in a temporal order. The narrator promises to resolve that tension if only the reader will patiently continue a little longer. Thus the act of reading narrative commits the reader to a kind of contract, which invests the reader in accepting the resolution, when it comes, as appropriate and satisfying (Sussman, 1998; Brooks, 1996). Despite narrative's predictable form, it must be unpredictable in the details to achieve the necessary aesthetic qualities of suspense and surprised relief. In this sense it invites the reader to engage in the particularistic judgment characteristic of aesthetic experience generally.

Narrative has always been involved in the legitimation of normative orders (Cover, 1983; Lyotard, 1984; MacIntyre, 1985). This is obvious in preliterate societies, which can only record and transmit their norms and political institutions in the form of memorable stories. But literacy begins with the transcription of these national or tribal epics. In modern society, such epics have been replaced

This article is (c) Emerald Publishing Limited and permission has been granted for this version to appear here (https://digitalcommons.law.buffalo.edu). Emerald does not grant permission for this article to be further copied/distributed or hosted elsewhere without the express permission from Emerald Publishing Limited. 
with more specialized discourses: narrative histories to record the origins and development of political institutions, narrative novels and memoirs to recount the interaction of character and role, and non-narrative law codes to fix norms and procedures. Yet these functionally distinct and formally disparate genres presuppose one another. Modern law tends to be seen as entrenching two large institutional structures: a more or less democratic nation state and a civil society of transacting individuals. The national history underwrites the first, by grounding an argument that law has organized a population into a political community capable of conferring its consent to governance (White, 1981; Bhaba, 1990). The novel and memoir underwrite the second, by warranting that the individual is capable of rationally and responsibly exercising the discretion inherent in legal personality (Gagnier, 1987; Gallagher, 1994; Lukacs, 1920; Lynch, 1998). At the same time, law gives these genres their subjects, organizing the polities whose careers are recounted in history, and the civil societies within which novelistic characters pursue their careers of romance, intrigue, and social climbing.

Authorization narratives play an essential role in law's justificatory discourse. The very concept of sanction involves the structure of a story, triggered by some deviation from a prescribed state of affairs, followed by an act of judgment, and a corrective response (Binder \& Weisberg, 2000). The official imposing a sanction justifies it as authorized by a prior act of legislation. The legislator defining the sanction justifies it as the path to a brighter future or the restoration of a disrupted past. Both official and legislator claim authority on the basis of prior acts of appointment or election.

Legal argument generally involves one of two forms of authorization narrative, depending on where the speaker locates the current dispute along the narrative arc between equilibrium disrupted and equilibrium restored. Archaelogical argument locates the disruptive crisis in the past. Thus, applicable legal norms have emerged from the authoritative settlement of that conflict. The current dispute is an echo of that earlier conflict and has, in effect already been settled. To decide otherwise is to reopen that conflict and reproduce the problems the applicable legal norm earlier solved. Teleological argument locates the disruptive crisis in the present. Thus, the current dispute results from a defective normative order, in which the needs of some are unmet or the goals of all are unrealized. The applicable legal norm will achieve the needed change. Archaeological argument predominates in litigation and teleological argument predominates in legislation. But many legal arguments combine both archaeological and teleological elements. Thus, the current dispute is governed by an earlier normative settlement that promulgated a collective goal as yet unachieved. Both teleological and archaeological narratives derive authority from a collective will that must be constructed in the act of representation.

Teleological representation involves prospective reasoning about the public interest or the social welfare. Such teleological representation involves imagining

This article is (c) Emerald Publishing Limited and permission has been granted for this version to appear here (https://digitalcommons.law.buffalo.edu). Emerald does not grant permission for this article to be further copied/distributed or hosted elsewhere without the express permission from Emerald Publishing Limited. 
and comparing the future histories of alternative hypothetical societies, each with not only different legal regimes, but also different populations with different values and interests. When different societies have different histories and institutional structures, they are likely to make available quite disparate social identities and roles to their members. These disparate identities and roles will encourage members of differently constituted societies to pursue different purposes and interests.

When we try to compare societies with different members, values, and interests from the standpoint of social welfare we face imponderables. Should you prefer a wealthier society in which you had a different family or personality? Should you prefer a more peaceful society in which you did not exist? The choice among such incommensurable alternatives is not the simple matter of calculating which future will be better for people because the alternatives are populated by different people. Such a decision requires us to choose among the different personal, group, institutional, and societal identities that will shape the preferences of future generations. We cannot hold their future preferences fixed and choose policies that will best realize them. Instead, the design of the future society, its membership, and its values is a necessarily expressive or aesthetic choice for us (Parfit, 1984; Binder, 2001).

We face further value choices in reasoning about the future welfare of society. We must choose distributive standards both within and across generations. We must choose a time horizon: the future is infinite, our knowledge of it finite and diminishing (Herzog, 1985). We must choose how to compare aggregate and average utility (Parfit, 1984). We must choose a geographic scope: Is each government responsible only for the welfare of the population in its territory? Even if its decisions may affect immigration and emigration? (Binder, 1993a). All these choices about how best to aggregate and compare subjectivity are themselves subjective. We cannot simply enact the preferences of future people, because we must decide which future people to consult, and what preferences they will have. These decisions inevitably depend on our value choices, not those of the future people whose welfare we would serve. Indeed, our value choices about future welfare are likely to be interpretive responses to the identities, roles, and traditions we have inherited from the past (Fish, 1989; Gadamer, 1975). We express ourselves in making these choices. We fashion a design for the future that is our best vision of how to continue a historical narrative in which we find ourselves (MacIntyre, 1985; Dworkin, 1986).

The inevitable discretion we have to shape the future preferences we would satisfy prevents teleological representation from achieving mimesis. From the standpoint of modernist criticism, teleological representation therefore seems illegitimate. In the face of the subjective, expressive, and arguably aesthetic value choices entailed in prospective policy making, it is tempting to revert to some form of archaeological representation. 
Archaeological representation consists in retrospective reasoning about indicia of societal consent. The difficulty is that notions like popular consent are incoherent and instable without authoritative institutional definition, and the institutions defining popular consent can ultimately find no warrant in popular consent. Institutional authority depends upon legitimating narratives, which make a persuasive appeal for a performative response (Lyotard, 1984). To judge the persuasiveness of these legitimating narratives, we must make expressive and aesthetic choices. Just as prospective reasoning about future welfare implicates aesthetic judgment, so does retrospective reasoning about past acts of consent.

Thus, when legal decisionmakers represent society's will, they again face a number of discretionary choices. First they must decide to what extent they are going to represent society as a single democratic decisionmaker, and to what extent they will represent society as a collection of individual transactors (Binder \& Weisberg, 1997). In other words, we can think of the tension between majoritarian democracy and individual liberty, or between political allocation and market allocation, as an aesthetic dilemma, a problem of representation. Each of these forms of representation reconciles conflicting preferences in a different way, and by assigning different decisions to different institutions we can represent the same individuals quite differently. Within each of these modes of representation there are further dilemmas, reflecting the indeterminacy of the ideals of majoritarian democracy, individual liberty, and allocative efficiency. The indeterminacy of these three ideals in turn reflects the opacity of the corresponding institutions of elections, legal rights, and market exchange as media for representing consent.

Majoritarian democracy is the conception of consent represented by the institution of elections. Yet as an ideal, majoritarian democracy is afflicted with the familiar problem of social choice. According to Arrow's classic demonstration, no social choice mechanism can aggregate fixed individual preference orderings of more than two alternatives into a coherent social preference ordering. A coherent social preference ordering therefore requires that individual preferences vary with and depend on the institution aggregating them into a collective choice (Arrow, 1963). The practical point of Arrow's voting paradox is not that indeterminacy is possible with three alternatives or more, but that indeterminacy is almost inevitable when the number of alternatives becomes very great. Democratic electorates must choose among an infinitely large set of alternative possible futures. If they do so through pairwise comparisons, the results are likely to depend on the order of comparison. If they try to compare all alternatives at once, different schemes for weighting preferences will yield different results (Mackie, 2003). In sum, the choice of voting procedures proves more important than voting in determining electoral choices. There is no simple fact of the matter about collective preferences for the institution of democracy to

This article is (c) Emerald Publishing Limited and permission has been granted for this version to appear here (https://digitalcommons.law.buffalo.edu). Emerald does not grant permission for this article to be further copied/distributed or hosted elsewhere without the express permission from Emerald Publishing Limited. 
represent. The figurative replacement of individual preferences by majority will is one type of reconciliation narrative.

As a conception of consent, majoritarian democracy is also necessarily incomplete. It depends on some set of procedural conditions designed to guarantee free and equal participation - universal suffrage, secret ballots, freedom of speech and press, and so on. These procedural conditions set limits to the power of democratic majorities to legislate: they cannot disfranchise, exile, enslave or exterminate minorities, for example, without destroying the conditions for majoritarian democracy. Majoritarian democracy is therefore a self-limiting ideal, requiring a supplementary scheme of individual rights (Holmes, 1995).

Individual liberty is the conception of consent represented by the institution of legal rights, supervised by the institution of courts. Liberty offers an alternative to majoritarian democracy as an organization of consent. If political processes cannot yield demonstrably legitimate choices, it is tempting to decrease the scope of political decisionmaking as much as possible, and increase the scope for individual decisionmaking. Thus the classical liberal thought popular among American and German lawyers of the mid- to late nineteenth century, attempted to restrict the domain of collective choice by recognizing individuals as autonomous within a sphere of purely self-regarding action. Individuals, it was said, were free to act as long as their actions imposed no harm on others. Classical liberals assumed that society was so designed that individuals had a wide scope within which they could act without effecting others, and reasoned that neither the state nor other individuals should interfere with such purely self-regarding action (Gordon, 1983; Singer, 1982). This vision of an atomistic society rested on a conception of property rights as relations between persons and things, and of the objects of property rights as environments - physical spaces paradigmatically within which individuals could act without affecting one another (Binder, 2002).

Yet such American legal realists as John Wesley Hohfeld and Walter Wheeler Cook argued persuasively that purely self-regarding action is a chimera. To use a resource is to interfere with rival potential uses, and to recognize a right of autonomy on the part of one person is to impose a duty of non-interference on the part of others. This analysis demonstrated that a property right was a social relation and that the object of property was always an arena of social interaction and conflict, rather than a peaceful private retreat (Cook, 1918; Cohen, 1927; Hohfeld, 1913; Coase, 1960; Singer, 1982). This meant in turn that the problem of collective choice cannot be solved simply by disaggregating it into a series of individual choices. Any such strategy depends on a social decision to distribute to individuals the right to exclude all others from access to certain resources. The ideal of individual liberty depends on the figurative replacement of conflicting desires with an authoritative allocation of rights. In short it depends upon the reconciliation of conflicting claims of justice, perhaps by a court. The need for

This article is $($ Emerald Publishing Limited and permission has been granted for this version to appear here (https://digitalcommons.law.buffalo.edu). Emerald does not grant permission for this article to be further copied/distributed or hosted elsewhere without the express permission from Emerald Publishing Limited. 
such an allocation of rights simply moves the problem of social choice back to an earlier stage.

Like the ideal of majoritarian democracy, the ideal of individual liberty is selflimiting. Some sort of politics must limit each person's liberty, to insure the equal, or at least minimally adequate liberty of others. And just as the unrestricted exercise of majoritarian democracy today may destroy the conditions for its exercise tomorrow, the unrestricted exercise of individual liberty in the present may waste the requisites of individual liberty in the future. Individuals may sell or indebt themselves into slavery, addict themselves to dangerous products, or enthrall themselves to exploitative creeds. To institutionalize individual liberty, society must make a political choice about how much paternalistic protection it will provide individuals.

Allocative efficiency is the conception of consent represented by the institution of market exchange. It offers a representation of desire that is collective, and yet not aggregative. In this way, it promises to resolve some questions of resource allocation in a way that responds to individual preferences, while avoiding the paradoxes of social choice theory. By hypothesis, when a resource is exchanged it is moved to a use that is more valuable socially, but without any social decisionmaker aggregating the utilities of the transacting parties. Assuming that a transaction is uncoerced, it should make both parties at least marginally better off. And assuming there are no transaction costs, anyone else whose welfare is decreased by the transaction can attempt to prevent it by bribing the parties forgo it (Coase, 1960). So if unrestricted opportunities for costless transactions are institutionalized, society should be able to constantly reallocate resources in ways that increase the welfare of some without decreasing the welfare of any. Assuming no transaction costs or coercion, market exchange should be able to allocate resources optimally, regardless of their initial distribution. By means of the reconciliation narrative of the invisible hand, individual desire is transformed into collective utility without the need for politics. But like majoritarian democracy and individual liberty, allocative efficiency is a necessarily incomplete representation of aggregate desire.

First, efficiency depends on politics. While efficiency presumes the ideal of costless transactions, all transactions involve the cost of enforcing promises and defining and securing entitlements to the resources traded. These costly services are typically provided by government without a fee. So the transactional model of collective decisionmaking presupposes a political process of collective decisionmaking to establish the institutions of property and contract within which transactional decisions will take place (Barzel, 2002; North, 1990; Rose, 1989).

Second, efficiency depends upon individual liberty. If choices are coerced, we cannot interpret them as welfare-maximizing revelations of preferences. And since all market choices are constrained by the available goods, and the limitations of the actor's purchasing power, market choices are all coerced in varying degree

This article is (c) Emerald Publishing Limited and permission has been granted for this version to appear here (https://digitalcommons.law.buffalo.edu). Emerald does not grant permission for this article to be further copied/distributed or hosted elsewhere without the express permission from Emerald Publishing Limited. 
(Crawford, 1997). Determining whether to deem a particular menu of options excessively coercive requires a collective, political judgment.

Third, any claim that uncoerced, costless transactions are allocatively efficient becomes circular, when combined with two premises of neo-classical economics: the behaviorist methodological assumptions that satisfaction cannot be reliably observed and that utility cannot be compared across persons (Robbins, 1938; Samuelson, 1938; Samuelson, 1950; Friedman, 1953). On these assumptions welfare must be defined behaviorally as the result of uncoerced, costless transactions; yet there is no way to determine if an actual or possible transaction meets these conditions without knowing its welfare effects. Economists recognize no independent measure of welfare by which they can determine whether coercion has caused, or transaction costs have prevented any particular transaction.

Just as an election cannot register each voter's preferences for all possible futures, a market cannot register each consumer's preferences for all possible goods and services. Consumers can only spend wealth they have, and only on the particular goods and services producers provide. Like electoral institutions and property, markets construct an arena for the exercise of choice and thereby create a medium for expressing desires choosers might not otherwise have (Anderson, 1993; Walzer, 1983).

Finally, like the ideals of majoritarian democracy and individual liberty, the ideal of allocative efficiency is self-limiting. Like voting and the exercise of property rights, market exchange can destroy its own institutional conditions. If individuals can sell themselves, or trade away the requisites of participation in market exchange, their preferences will no longer influence market allocation. The unrestricted transacting required for efficient allocation is a procedural impossibility. Politics must create and define markets, as well as spheres of individual liberty.

We have seen that each of the idioms for representing consent - majoritarian democracy, individual liberty, and allocative efficiency - is an opaque medium. Thus, each medium of archaeological representation constructs the consent that it represents. But when legal decisionmakers represent societal will they must not only choose within each idiom, they must also choose among them. In designing the institutions of electoral politics, individual rights, and market exchange, legal decisionmakers are not only influencing the particular goals and policies to which members of society consent, they are also shaping the forms of consent democracy, liberty, or efficiency - made available to them. The design of a mix of institutions for registering consent is itself a social or political choice that cannot be justified by consent alone, without an infinite regress.

But if neither future social welfare nor past consent can legitimate legal institutions what can? Such institutions can only be rendered authoritative by means of a legitimating narrative. Legitimation narratives present particular legal institutions as their audience's proper path from virtuous origins to future well- 
being. They make a performative appeal, inviting an audience to identify itself with a particular institutional medium for representing desire. Such legitimating narratives are a necessary part of legal argument, because without them, legal argument cannot warrant particular archaeological and teleological representations of societal will as authoritative. A narrative of virtuous institutional origins is needed to cope with two related problems of liberal political theory, the problem of collective action and the problem of political obligation.

The collective action problem arises among individuals who are rationally selfinterested, uncoerced, and well-informed. Such persons have no incentive to cooperate in producing or conserving public goods such as renewable resources, common defense, or security of entitlements. By defecting, they can receive the benefits of the public good without bearing the costs of its provision. Hence all will find it rational to defect, with the perverse result that none will enjoy the public good (Olson, 1965). And so, the argument concludes, government is needed to coerce free riders into cooperating to produce public goods. Convinced by the security of government enforcement that one's fellow citizens will cooperate in the provision of public goods, each citizen will ungrudgingly cooperate in turn.

But this willingness depends upon each citizen's faith in the stability, effectiveness, and civic responsibility of the institutions charged with enforcing cooperation. And rational self-interest maximizers will be very skeptical of promises to establish a stable and effective rule of law. For such a government is itself a public good requiring cooperation to establish. So government arguably could never come into existence among people who were uncoerced, rationally self-interested, and well-informed, even if they desired it (Rose, 1989).

The existence of an effective liberal government therefore presupposes a prior history involving coercion, altruism, or myth. Coercion can play at least two roles in establishing liberal government. A liberal government can arise as a result of the internal reform of an authoritarian state or as a result of a violent revolution, establishing military rule before building liberal institutions. Yet a revolutionary movement is also an irrationally cooperative enterprise that must be explained in terms of coercion, altruism or myth. By altruism, I mean a disposition to cooperate regardless of the defection of free riders. Altruism can play a role in establishing effective government when tribal, religious or ideological solidarity becomes a basis for civic loyalty. By myth I mean faith that others will cooperate in obeying and defending government when this has not been proven by experience. Typically, myth takes the form of an invented past characterized by heroic altruism, solidaristic cooperation, and virtuous government. A myth of national origin can support a solidaristic ideology (Binder \& Weisberg, 2000; Anderson, 1983; Gellner, 1983). Historically speaking, modern liberal states arise through a combination of these processes, rather than through uncoerced contracting among rationally self-interested individuals. Indeed, we are unlikely to see rationally self- 
interested individuals unencumbered by solidaristic commitments or authoritarian beliefs except in a liberal state. Rationality can only be the product of liberal institutions, not their source.

In addition to solving the collective action problem, a mythic narrative of a heroic founding can solve a related problem, that of political obligation. This problem arises in consent theories of political legitimacy. If government derives its legitimacy only from the consent of the governed, it is not clear why its citizens should comply with laws they do not personally agree to. Nor is it clear why anyone born into such a society (rather than joining it voluntarily) should respect its laws. Revolutionary origins symbolize the moral basis of many modern states in the consent of the governed, yet they also illustrate the fragility of such a foundation. Every legal system must account for its origins in an act of transgression against a preexisting legal order (Cover, 1983). So a state's revolutionary origin poses the problem of political obligation, unless it provides some additional basis of legitimacy beyond consent. That is why a myth of revolutionary heroism is particular important: a reputation for extraordinary virtue is needed to explain why the founding generation had a right to revolt, but their successors do not.

The liberal state cannot induce cooperation and provide public goods unless it is stable. But it cannot promise stability if it holds that citizens are only bound to obey law as long as they consent to do so. The disenchanted liberal individual, loyal only to his own property, cannot by himself sustain the polity that protects it. Thus the authority of the liberal state can never be explained by reference to consent alone. To solve the problem of political obligation, the narrative mythology of the liberal state must offer a reason why the consent of the founders binds their successors. To distinguish the founding exercise of will from future defections, it must be remembered as virtuous, motivated by altruism rather than selfishness. The popular "consent"' which legitimates new laws is not purely a matter of will: it is a matter of keeping faith with virtues that a patriotic mythology ascribes to a political founding. When we make law, we do not simply reveal preference: we exercise the authority of office. Our consent can only authorize law, if we have first characterized ourselves as authoritative, in an act of literary imagination (Vining, 1988; Derrida, 1986).

Thus the claim that a legal system makes to legitimacy is not simply a claim about ethics, or about political fact. It is a performative appeal that offers each citizen recognition as a member of a particular political community. It must offer not only just and efficacious institutions, but an identity which each citizen will perceive as appealing to all, and so which may plausibly promise to bind each citizen to those institutions. It demands of each citizen a performative response, identifying with a political community and thereby recognizing other citizens as members. To thus identify herself with a political community and its other members, is to make an expressive choice (Ankersmit, 1996). And such an 
expressive choice depends on at least two kinds of judgment that can fairly be characterized as aesthetic. First, in choosing an identity for herself and others she chooses purposes. Second, in choosing an identity to share with others, she must interpret a collective project. Such judgments are too subjective and historically contingent to count as moral, yet they are aimed at selfconstitution rather than merely self-gratification.

\section{CONCLUSION: THE AESTHETIC PREDICAMENT OF LEGAL CRITICISM}

In liberal states legal arguments depend on representations of human will, taking the form of judgments about future social welfare or past popular consent. Yet these representations are not simply mimetic, because social welfare and popular will are constituted in the very act of representing them. The process by which we represent our society's will and welfare in the medium of law is an imaginative and expressive one, narrating the path from a virtuous past to a decent future, and informed by aesthetic judgment as well as instrumental reason. In so far as law involves the presentation of rhetoric for aesthetic judgment it is a literary practice.

Recognizing the constitutively aesthetic basis of legal justification in the liberal state should induce us to revise the practice of modernist criticism of law. Much contemporary critical scholarship accepts the modernist premise that law should mirror the desires of society's members and takes law to task for failing to do so with perfect accuracy. Such mimetic criticism is subject to two pathologies: skepticism and sentimentalism

Skepticism is the disposition to see every practice as illegitimate unless it can be shown to rest on some indubitable foundation independent of the practice (Binder \& Weisberg, 2000). Mimetic criticism becomes skeptical when it tries, and fails, to turn societal will into such a foundation for law. The skeptical form of mimetic criticism tends to begin with the proposition that political representation always involves an agency problem, a potential conflict between the interests of the represented and the interests of those who represent them. Accordingly, skeptical criticism deems representation legitimate only if the medium of representation is transparent: that is, only if it can simply copy the represented, without involving any discretionary choices. But as we have seen, political representation cannot be transparent in this sense. The teleological representation of welfare and the archaeological representation of consent are both inevitably discretionary acts of imaginative construction.

Mimetic critics tend to treat each of the paradoxes and limitations of majoritarian democracy, individual liberty, and allocative efficiency separately. Thus, one points to the problems of social choice theory in arguing that we can represent society more accurately by shifting decisionmaking authority from state to market (Riker, 1982; Riker \& Ordeshook, 1973). Or, one points to the legal 
rights problem, and the indeterminacy of allocative efficiency in arguing that we can represent society more accurately in shifting decisionmaking authority from individuals and markets to the state (Sunstein, 1986). Each argument is based on the fallacious premise that a more accurate, less discretionary, depiction of society is possible, or even desirable. The mimetic critic appears to be saying something constructive about which institutions should have the leading role in governing society, but he is merely bearing witness to the opacity inherent in any institutional representation of society.

Skeptical variants of mimetic criticism recognize the opacity of both state and market as representative institutions, but nevertheless insist that legitimate law must stand on a foundation of actual consent, warranted by law's mimetic resemblance to society. Skeptical criticism reasons that since law must be a transparent medium of representation, and legal decisionmakers necessarily have discretion as to how they represent society, these decisionmakers rule society rather than taking instruction from society (Tushnet, 1988; Levinson, 1988). One response to this skeptical conclusion is a flight to the formalist ideal of the rule of law. According to this view, law must constrain legal decisionmakers with rules, to prevent them from ruling oppressively. The skeptic will likely respond that since any such scheme of rules is subject to discretionary interpretation, no such scheme can prevent the oppressive exercise of discretion (Tushnet, 1988). But rule formalism has also provoked a second and equally pathological form of mimetic criticism: sentimentalist criticism.

Sentimentality is the experience of pleasure in emotion. By sentimentalism I mean a sanctimonious insistence on insulating this pleasure from the threat of critical reflection (Binder \& Weisberg, 2000). Mimetic criticism becomes sentimentalist when it venerates individual or group subjectivity as the occasion for sentimental experience, and so tries to protect it from the representative mediation necessary to any institutional order. Sentimental criticism of law argues that formal rules designed to constrain official discretion are arbitrary and inflexible. The result is that decision according to rule will not yield outcomes the represented would choose. It follows that such legal rules cannot express the true subjectivity of those whom law represents, and the rule of law therefore demeans those subject to it (Abrams, 1991; Getman, 1988; Weisberg, 1984, 1992; White, 1990). The sentimentalist complaint is not that the rule of law oppresses, but that it fails to recognize, express, and empathize with the personality of the legal subject. The demand is not that law should construct some serviceable representation of the will of those subject to it, but that it should represent their authentic feelings and identities.

But the demand that law represent its subject authentically misunderstands what political representation is. It is not an effort to copy a preexisting fact about the public good, but an effort to construct the public good. At an early stage in the development of the liberal state, Hegel offered an analysis of the problem of

This article is (c) Emerald Publishing Limited and permission has been granted for this version to appear here (https://digitalcommons.law.buffalo.edu). Emerald does not grant permission for this article to be further copied/distributed or hosted elsewhere without the express permission from Emerald Publishing Limited. 
legitimacy as a challenge to universalize recognition and civic dignity in a dynamically competitive economic environment. Hegel saw that recognition in a dynamic society had to be dialectical rather than mimetic. The state had to enable the citizen's self-conscious transformation and development rather than preserve the conditions for a static identity. For example, to enable the individual to participate in the dignity of collective self-governance, the liberal state had to encourage cooperation by fostering the institutions of civil society (Hegel, 1942; Binder, 1993b).

Both skeptical and sentimental variants of mimetic criticism set unrealistically high standards of accuracy and fidelity in representation. Skeptical criticism demands that knowledge of social will rest on indubitable epistemological foundations, even though pragmatism demands only that beliefs be justified by comparing their consequences to those of available alternatives. Sentimental criticism demands that representations capture the full particularity and intrinsic worth of each individual, even when reductive generalization may serve as a useful tool of practical reason. Sentimental criticism requires that law treat its subjects with all the tenderness and insight appropriate to an intimate interpersonal relationship, providing a kind of civic substitute for love.

Yet law has the more modest ambitions of keeping the peace and organizing collective action. And if it is to realize these more prosaic ambitions, law will inevitably require institutions with arbitrary decisionmaking procedures and coercive power, a division of labor with attendant agency problems, and tradeoffs among competing values. In particular, representative democracy, contract, some sort of property, and the rule of law have all proven themselves necessary components of productive, peaceful, and politically responsive societies. Skeptical and sentimental criticisms do not offer practical alternatives to the institutions they criticize. This suggests that from the pragmatic standpoint, aesthetic standards such as social decency are more germane in evaluating law than mimetic standards such as representative accuracy or faithful agency (Binder, 2001).

Mimetic criticism is useless to normative practice because it searches obsessively for a foundation that cannot possibly exist. Mimetic criticism misconceives the nature of law's representation of society. As we have seen, there is no fixed fact of the matter about individual subjectivity that law can represent in the process of organizing collective action. The individual preferences measured, aggregated, and represented by institutions such as elections and markets are endogenous to those institutions. Individual preferences depend on the social settings for the development and expression of choice. Collective preferences depend on the methods by which institutions identify them. The current freedom of individuals and collectivities to choose is at odds with their future freedom, and the future welfare of society depends on how we choose to constitute that society and measure its will. In sum, individual and societal will

This article is ( E) Emerald Publishing Limited and permission has been granted for this version to appear here (https://digitalcommons.law.buffalo.edu). Emerald does not grant permission for this article to be further copied/distributed or hosted elsewhere without the express permission from Emerald Publishing Limited. 
and welfare are not facts which exist independent of law. Legal concepts such as public interest, contractual consent, and legislative intent are institutional constructs, not independent facts about society. This means that the mimetic conception of law's representation of society is premised on a fallacy. Apart from law, society has no determinate features for law to represent.

Because law does not - and cannot - mimic the will of society or of legal actors, critical scholarship about law should no longer be organized by a mimetic conception of law. Mimetic criticism should be replaced by aesthetic criticism, premised on a pragmatist model of justification and an institutionalist conception of law. Such aesthetic criticism presumes that law ascribes intentions and preferences, conditions choice, and organizes institutional settings for the discursive development of interests and goals. This means that law represents legal persons in something like the way a novel represents characters, and law represents legal interests and values the way a novel represents themes.

Aesthetic criticism sees law as an arena of cultural contestation and tries to understand it from the standpoint of legal actors for whom it is an expressive as well as a strategic practice. Thus, the strategic interests legal actors pursue are given by identities and roles - which are shaped in part by law. In particular, the legal activities of disputing, transacting, and decisionmaking provide opportunities to claim, perform, and define identities and roles. In so doing actors reproduce and reshape the law and thereby affect the expressive resources available to themselves and others. Aesthetic criticism must recognize that our legal institutions, our social identities and our individual interests are mutually constitutive elements of culture. It is this entire culture that is the proper object of critique, not legal institutions taken in isolation. In helping to fashion such a culture, law of course influences the interests we will define and pursue. But perhaps more importantly, law helps determine our identities and most fundamental values (Binder \& Weisberg, 1997). In evaluating alternative futures, we should be more concerned with what passions will fire our souls, than with how efficiently society will gratify those passions.

To evaluate, critique, and improve law, we must give up the comforting assumption that there is any fact of the matter about society's purposes for law to replicate. Society constructs its purposes along with its institutional organization. The choices society must make in thus creating itself are aesthetic choices. In a democratic polity, these choices must be made reflectively, as a result of a public discourse of aesthetic criticism.

\section{REFERENCES}

Abrams, K. (1991). Hearing the call of stories. California Law Review, 79, p. 973.

This article is (c) Emerald Publishing Limited and permission has been granted for this version to appear here (https://digitalcommons.law.buffalo.edu). Emerald does not grant permission for this article to be further copied/distributed or hosted elsewhere without the express permission from Emerald Publishing Limited. 
Ackerman, B. (1980). Social justice in the liberal state. New Haven: Yale University Press.

Anderson, B. (1983). Imagined communities: Reflections on the origins and spread of nationalism. London: Verso.

Anderson, E. (1993). Value in ethics and economics. Cambridge: Harvard University Press.

Ankersmit, F. R. (1996). Aesthetic politics. Stanford: Stanford University Press.

Arendt, H. (1992). Lectures on Kant's political philosophy. Chicago: University of Chicago Press.

Arrow, K. (1963). Social choice and individual values. New York: Wiley.

Austin, J. (1873). Lectures on jurisprudence. London: J. Murray.

Barzel, Y. (2002). A theory of the state. Cambridge: Cambridge University Press.

Bentham, J. (1996). An introduction to the principles of morals and legislation. Cambridge: Cambridge University Press.

Bhaba, H. (1990). DissemiNation: Time, narrative and the margins of the modern nation. In: H. Bhaba (Ed.), Nation and narration (pp. 291-321). London: Routledge.

Binder, G. (1993a). The case for self-determination. Stanford Journal of International Law, 29, p. 223.

Binder, G. (1993b). Post-totalitarian politics. Michigan Law Review, 91, p. 1491.

Binder, G. (2001). The poetics of the pragmatic. Stanford Law Review, 53, p. 1509.

Binder, G. (2002). Twentieth century legal metaphors for self and society. In: A. Sarat, B. Garth \& R. Kagan (Eds), Looking back at law's century (pp. 151-183). Ithaca: Cornell University Press.

Binder, G., \& Weisberg, R. (1997). Cultural criticism of law. Stanford Law Review, 49, p. 1149.

Binder, G., \& Weisberg, R. (2000). Literary criticisms of law. Princeton: Princeton University Press.

Bourdieu, P. (1977). Outline of a theory of practice (Richard Nice, Trans.). New York: Cambridge University Press.

Bourdieu, P. (1990). The logic of practice (Richard Nice, Trans.). Stanford: Stanford University Press. Bourdieu, P. (1991). Language and symbolic power (Gino Raymond and Matthew Adamson, Trans.). Cambridge: Harvard University Press.

Brooks, P. (1996). Reading for the plot. In: M. J. Hoffman \& P. D. Murphy (Eds), Essentials of the theory of fiction (p. 327). Durham: Duke University Press.

Cardozo, B. (1921). The nature of the judicial process. New Haven: Yale University Press.

Coase, R. (1960). The problem of social cost. Journal of Law and Economics, 1.

Cohen, F. (1935).Transcendental nonsense and the functional approach. Columbia Law Review, p. 809.

Cohen, M. (1927). Property and sovereignty. Cornell Law Quarterly, 1.

Cook, W. W. (1918). The privileges of labor unions in the struggle for life. Yale Law Journal, 27, p. 779.

Cover, R. (1983). The Supreme Court, 1982 term - foreword: Nomos and narrative. Harvard Law Review, 97, p. 4.

Crawford, P. (1997). The utility of the efficiency/equity dichotomy in tax policy analysis. Virginia Tax Review, 16, p. 501.

Culler, J. (1975). Structuralist poetics. New York: Cornell University Press.

Culler, J. (1983). On deconstruction. New York: Cornell University Press.

Derrida, J. (1976). Of grammatology. Baltimore: Johns Hopkins University Press.

Derrida, J. (1986). Declarations of independence. New Political Science, 15, p. 9.

Dworkin, R. (1986). Law's empire. Cambridge: Harvard University Press.

Fish, S. (1989). Doing what comes naturally: Change, rhetoric and the practice of theory in literary and legal studies. Durham: Duke University Press.

This article is (c) Emerald Publishing Limited and permission has been granted for this version to appear here (https://digitalcommons.law.buffalo.edu). Emerald does not grant permission for this article to be further copied/distributed or hosted elsewhere without the express permission from Emerald Publishing Limited. 
Friedman, M. (1953). The methodology of positive economics. In Essays in Positive Economics (Vol. 3). Chicago: University of Chicago Press.

Gadamer, H.-G. (1975). Truth and method. New York: The Seabury Press.

Gagnier, R. (1987). Social atoms, working class autobiography, subjectivity and gender. Victorian Studies, 30, p. 335.

Gallagher, C. (1994). Nobody's story: The vanishing acts of women writers in the marketplace, 1670-1820. Berkeley: University of California Press.

Gellner, E. (1983). Nations and nationalism. Ithaca: Cornell University Press.

Getman, J. J. (1988). Voices. Texas Law Review, 66, p. 577.

Gordon, R. (1983). Legal thought and legal practice in the age of American enterprise, 1870-1920. In: G. Geison (Ed.), Professions and professional ideologies in America. Chapel Hill: UNC Press.

Green, D., \& Shapiro, I. (1994). Pathologies of rational choice theory. New Haven: Yale University Press.

Habermas, J. (1996). Between facts and norms: Contributions to a discourse theory of law and democracy (William Rehg, Trans.). Cambridge: MIT Press.

Hart, H. L. A. (1994). The concept of law. Oxford: Clarendon.

Hegel, G.W.F. (1942). The Philosophy of Right (T. M. Knox, Trans.). Oxford: Clarendon.

Herzog, D. (1985). Without foundations: Justification in political theory. Ithaca: Cornell University Press.

Hohfeld, W. (1913). Some fundamental legal conceptions as applied in judicial reasoning. Yale Law Journal, 23, p. 16.

Holmes, S. (1995). Passions and constraint: On the theory of liberal democracy. Chicago: University of Chicago Press.

Hurley, S. L. (1989). Natural reasons. Oxford: Oxford University Press.

Kant, I. (1986). The Critique of Judgment (James Creed Meredith, Trans.). Oxford: Oxford University Press.

Komesar, N. (1997). Imperfect alternatives; choosing institutions in law, economics and public policy. Chicago: University of Chicago Press.

Levinson, S. (1988). Law as literature. In: S. Levinson \& S. Mailloux (Eds), Interpreting law and literature: A hermeneutic reader (pp. 155-175). Evanston: Northwestern University Press.

Lieber, F. (1839). Legal and political hermeneutics. Boston: Little, Brown.

Llewellyn, K. (1960). The common law tradition. Boston: Little, Brown.

Luban, D. (1988). Lawyers and justice: An ethical study. Princeton: Princeton University Press.

Lukacs, G. (1920). The theory of the novel. Cambridge: MIT Press.

Lynch, D. S. (1998). The economy of character: Novels, market culture and the business of inner meaning. Chicago: University of Chicago Press.

Lyotard, F. (1984). The postmodern condition: A report on knowledge. Minneapolis: University of Minnesota Press.

MacCormick, N., \& Weinberger, O. (1986). An institutional theory of law. Boston: D. Reidel Publishing Company.

MacIntyre, A. (1985). After virtue: A study in moral theory. South Bend: University Notre Dame Press.

Mackie, G. (2003). Democracy defended. Cambridge: Cambridge University Press.

March, J., \& Olsen, J. (1989). Rediscovering institutions. New York: Free Press.

March, J., \& Olsen, J. (1995). Democratic governance. New York City: The Free Press.

Margulies, P. (1996). The lawyer as caregiver: Child client's competence in context. Fordham Law Review, 64, p. 1473.

This article is (c) Emerald Publishing Limited and permission has been granted for this version to appear here (https://digitalcommons.law.buffalo.edu). Emerald does not grant permission for this article to be further copied/distributed or hosted elsewhere without the express permission from Emerald Publishing Limited. 
Nehamas, A. (1985). Nietzsche: Life and literature. Cambridge: Harvard University Press.

Nietzsche, F. (1974). The gay science. (Walter Kaufman, Trans.). New York: Random House.

North, D. (1990). Institutions, institutional change and economic performance. Cambridge: Cambridge University Press.

Olson, M. (1965). The logic of collective action: Public goods and the theory of groups. Cambridge: Harvard University Press.

Parfit, D. (1984). Reasons and persons. Oxford: Oxford University Press.

Patterson, D. (1996). Law and truth. New York: Oxford University Press.

Peirce, C. S. (1931-1935). Collected Papers (Vol. 5). Cambridge, MA: Harvard University Press. Peters, G. (1999). Institutional theory in political science. New York City: Pinter.

Pildes, R., \& Anderson, E. (1990). Slinging arrows at democracy. Columbia Law Review, 90, p. 2121.

Pitkin, H. (1967). The concept of representation. Berkley: University of California Press, Ltd.

Posner, R. (1973). Economic analysis of law. Boston: Little, Brown.

Quine, W. V. O. (1963). From a logical point of view. New York: Harper \& Row.

Riker, W. (1982). Liberalism against populism. Prospect Heights: Waveland Press.

Riker, W., \& Ordeshook, P. (1973). An introduction to positive political theory. Englewood Cliffs: Prentice-Hall.

Robbins, L. (1938). Interpersonal comparisons of utility: A comment. Economic Journal, 48, p. 635.

Rorty, R. (1979). Philosophy and the mirror of nature. Princeton: Princeton University Press.

Rose, C. (1989). Property as storytelling. Yale Journal of Law \& the Humanities, 2, p. 37.

Ruiter, D. (1993). Institutional legal facts. Boston: Kluwer Academic Publishers.

Samuelson, P. (1938). A note on the pure theory of consumer behavior. Economica, 5, p. 61.

Samuelson, P. (1950). The problem of integrability in utility theory. Economica, 17, p. 355. de Saussure, F. (1959). General course of linguistics. In: W. Baskin (Trans.). New York: McGraw-Hill. Schiller, F. (1967). Letters on the aesthetic education of man. (Ed. and Trans., E. M. Wilkinson and L.A. Willoughby). Oxford: Clarendon.

Scholes, R., \& Kellogg, R. (1966). The nature of narrative. New York: Oxford University Press.

Scott, R. (1995). Institutions and organizations. Thousand Oaks: Sage Publications.

Searle, J. (1995). The construction of social reality. New York City: The Free Press.

Simon, W. (1978). The ideology of advocacy: Procedural justice and professional ethics. Wisconsin Law Review, p. 29.

Singer, J. (1982). The legal rights debate from Bentham to Hohfeld. Wisconsin Law Review, p. 975.

Singer, J. (1984). The player \& the cards: Nihilism and legal theory. Yale Law Journal, 94, p. 1.

Skidelsky, R. (2006). Drawing a dog in Iraq. NewYork Review of Books, October 6.

Sunstein, C. (1986). Legal interference with private preferences. University of Chicago Law Review, 53, p. 1125.

Sussman, H. (1998). The aesthetic contract: Statutes of art and intellectual work in modernity. Stanford: Stanford University Press.

Todorov, T. (1971). The poetics of prose (Richard Howard, Trans.). Ithaca: Cornell University Press. Tushnet, M. (1988). Red, white and blue: A critical analysis of constitutional law. Cambridge, MA: Harvard University Press.

Vining, J. (1988). The authoritative and the authoritarian. Chicago: University of Chicago Press.

Walzer, M. (1983). Spheres of justice. New York City: Basic Books.

Weisberg, R. (1984). The failure of the word. New Haven: Yale University Press.

Weisberg, R. (1988). The law-literature enterprise. Yale Journal of Law \& the Humanities, 1, p. 1.

Weisberg, R. (1992). Poethics and other strategies of law and literature. New York: Columbia University Press.

This article is (c) Emerald Publishing Limited and permission has been granted for this version to appear here (https://digitalcommons.law.buffalo.edu). Emerald does not grant permission for this article to be further copied/distributed or hosted elsewhere without the express permission from Emerald Publishing Limited. 
White, H. (1981). The value of narrative in the representation of reality. In: W. J. T. Mitchell (Ed.), On narrative. Chicago: University of Chicago Press.

White, L. (1990). Subordination, rhetorical survival skills, and sunday shoes: Notes on the hearing of Mrs. G.. Buffalo Law Review, A38, p. 1.

Williston, S. (1920). The law of contracts. New York: Baker, Voorhis.

Winter, S. (1989). The cognitive dimension of the agon between legal power and narrative meaning. Michigan Law Review, 87, p. 2225.

Wittgenstein, L. (1968). Philosophical investigations. New York: Macmillan.

This article is (c) Emerald Publishing Limited and permission has been granted for this version to appear here (https://digitalcommons.law.buffalo.edu). Emerald does not grant permission for this article to be further copied/distributed or hosted elsewhere without the express permission from Emerald Publishing Limited. 